\title{
TRANSFORMATIONAL LEADERSH IP, MEANING IN WORK, LEADER MEMBER EXCHANGE (LMX), JOB PERFORMANCE DAN WORK ENGAGEMENT
}

\author{
Didik Joko Pitoyo \\ PT. Kusumaputra Santosa \\ H unik Sri Runing Sawitri \\ Fakultas Ekonomi dan Bisnis Universitas Sebelas Maret
}

\begin{abstract}
The purpose of this study was to analyze the influence of meaning in work as intervening variable relationship between transformational leadership and work engagement and analyze the effect of work engagement as pemediasi variable relationship between leader-member exchange and job performance. This study uses a quantitative research methods. While the sample used this study as many as 213 people in the PT Kusumaputra Santosa Karanganyar. The data analysis techniques using multiple linear regression analysis method path.

Results of this study are a) Transformational leadership significant effect on work engagement. b) Transformational leadership and meaning in work significant effect on work engagement. c) meaning in work can be a mediating variable and is expressed as a partial mediating variables (partial mediation). This is because, after entering the variable Meaning in Work, due to the influence of the variable Work Engagement Transformational Leadership which was significantly be remained significant after entering Meaning in Work variables into the regression equation model but declined regression coefficient. d) LMX significant effect on job performance. e) LMX and work engagement significant effect on job performance. f) Work engagement can be a mediating variable and is expressed as a partial mediating variables (partial mediation). This is because, the influence of variables leader member exchange for job performance that was significantly be remained significant after entering work engagement variable into the regression model but declined regression coefficient.
\end{abstract}

Keywords: Transformational Leadership, meaning in work, LMX, Job Performance, Work Engagement.

\section{ABSTRAK}

Tujuan penelitian ini adalah menganalisis pengaruh meaning in work sebagai variabel pemediasi hubungan antara transformational leadership dan work engagement dan menganalisis pengaruh work engagement sebagai variabel pemediasi hubungan antara leader-member exchange dan job performance. Penelitian ini menggunakan metode penelitian kuantitatif. Sementara itu sampel yang digunakan penelitian ini sebanyak 213 orang di PT Kusumaputra Santosa Karanganyar. Adapun teknik analisis data menggunakan regresi linier berganda dengan metode analisis path. 
Hasil penelitian ini adalah a) Transformational leadership berpengaruh signifikan terhadap work engagement. b) Transformational leadership dan meaning in work berpengaruh signifikan terhadap work engagement. c) meaning in work dapat menjadi variabel mediasi dan dinyatakan sebagai variabel mediasi parsial (partial mediation). Hal ini dikarenakan, setelah memasukan variabel Meaning in Work, karena pengaruh variabel Transformational Leadership terhadap Work Engagement yang tadinya signifikan menjadi tetap signifikan setelah memasukan variabel Meaning in Work ke dalam model persamaan regresi tetapi mengalami penurunan koefesien regresi. d) LMX berpengaruh signifikan terhadap job performance. e) LMX dan work engagement berpengaruh signifikan terhadap job performance. f) Work engagement dapat menjadi variabel mediasi dan dinyatakan sebagai variabel mediasi parsial (partial mediation). Hal ini dikarenakan, pengaruh variabel variabel leader member exchange terhadap job performance yang tadinya signifikan menjadi tetap signifikan setelah memasukan variabel work engagement ke dalam model persamaan regresi tetapi mengalami penurunan koefesien regresi.

Kata Kunci: Transformational Leadership, LMX, Job Performance, Work Engagement

Perkembangan sumberdaya manusia dalam sebuah industri dan organisasi dewasa ini semakin berkembang pesat. Sumberdaya manusia menjadi salah satu aspek penting untuk menghasilkan ketercapaian suatu visi, misi, dan tujuan yang hendak dicapai sebuah organisasi. Di tengah persaingan industri yang ketat, perusahaan tidak hanya merekrut karyawan berdasarkan bakat dan kemampuan saja, tetapi juga harus menginspirasi dan memungkinkan karyawan untuk mengaplikasikan dan memunculkan kemampuan dalam pekerjaan.

Organisasi dapat berjalan jika di dalamnya terdapat keterlibatan karyawan yang mampu mengubah perencanaan menjadi implementasi. Oleh karena itu, diperlukan peran kepemimpinan untuk dapat mempengaruhi karyawan agar bersedia terlibat. Bass et al. (2003) menjelaskan kemampuan pemimpin transformasional mengubah sistem nilai bawahan demi mencapai tujuan diperoleh dengan mengembangkan salah satu atau seluruh faktor yang merupakan dimensi kepemimpinan transformasional, yaitu: karisma (kemudian diubah menjadi pengaruh ideal atau idealized influence), inspirasi (inspirational motivation), pengembangan intelektual (intellectual stimulation), dan perhatian pribadi (individualized consideration).

Hubungan antara atasan dengan bawahan dalam konteks kepemimpinan transformasional lebih dari sekedar pertukaran "komoditas" (pertukaran imbalan secara ekonomis), tapi sudah menyentuh sistem nilai (value system). Pemimpin transformasional mampu menyatukan seluruh bawahannya dan mampu mengubah keyakinan (beliefs), sikap, dan tujuan pribadi masing-masing bawahan demi mencapai tujuan, bahkan melampaui tujuan yang ditetapkan (Humphreys, 2002).

Keterlibatan karyawan merupakan salah satu output yang ditunjukkan karyawan dalam aktivitas bekerjanya. Semakin keterlibatan karwayan tinggi dalam perusahaan, semakin mengindikasikan kinerjanya juga meningkat. Seorang karyawan bersedia untuk terlibat pastinya ada sebab dan tujuan tertentu, sehingga ini menarik untuk diketahui apa saja yang membuat seorang karyawan bersedia terlibat dalam bekerja. Gadhi (2013) mendapatkan 2 hasil temuan penelitian, dimana secara langsung 
kepemimpinan

transformasional

berpengaruh positif terhadap keterlibatan kerja dan secara tidak langsung makna kerja mampu menjadi mediasi parsial pada kepemimpinan transformasional terhadap keterlibatan kerja. Sedangkan Podolny (2005) mendapatkan temuan bahwa para pemimpin memainkan peran penting dalam membentuk atau mempengaruhi meaning in work bawahannya.

Pemimpin menggunakan visi, misi dan tujuan, serta identitas organisasi untuk mempengaruhi persepsi karyawan tentang meaning in work. Keadaan tersebut, memiliki pengaruh penting pada meaning in work pada karyawan. Ditambahkan juga, Mei et al. (2004) Work engagement diteliti sebagai konsekuensi untuk menemukan makna dalam pekerjaan. Hasil penelitian menunjukkan bahwa makna dalam pekerjaan merupakan faktor motivasi intrinsik yang memprediksi work engagement. Di sisi lain, Gallup (2009) mendapatkan temuan bahwa selama masa dihabiskan di tempat kerja ketika karyawan sedang terlibat, karyawan akan menghargai pekerjaan yang mereka lakukan dan hal tersebut menunjukkan pentingnya dan nilai-nilai dari peran kerja. Bakker (2010) sebagai peneliti yang fokus meneliti tentang work engagement menegaskan bahwa karyawan dapat secara aktif mengubah desain pekerjaan mereka dengan memilih tugas, negosiasi konten pekerjaan yang berbeda dan menetapkan makna untuk tugas-tugas pekerjaan yang dilakukan.

Penelitian tentang keterlibatan kerja akan lebih menarik jika dilakukan di perusahaan yang mempunyai jumlah karyawan yang banyak. Hal ini dikarenakan, semakin banyak karyawan dalam perusahaan maka permasalahan yang dihadapi oleh perusahaan juga semakin kompleks. Dalam penelitian ini, akan dilakukan di PT Kusumaputra Santosa, Karanganyar. Sebagai perusahaan padat karya, yang melibatkan banyak orang untuk berperan di dalamnya PT Kusumaputra Santosa membutuhkan manajemen sumberdaya manusia yang relevan agar tujuan organisasi tercapai di setiap periodenya. Kinerja karyawan di PT
Kusumaputra Santosa bisa dilihat dari tiga aspek yaitu KJA (Key Job Accountability), KPT (kompetensi) dan disiplin. Ketiga aspek tersebut merupakan indikator nyata dari karyawan dalam memperlihatkan keterlibatannya di perusahaan.

\section{TELAAH PUSTAKA}

\section{Work Engagement}

Work engagement didefinisikan pertama kali oleh Kahn (1990) sebagai suatu keadaan dimana anggota dari sebuah organisasi melibatkan dirinya dengan pekerjaannya. Robinson, Perryman, \& Hayday (2004) mendefinisikan work engagement sebagai sikap positif karyawan terhadap organisasi dan nilai-nilai organisasi. Karyawan yang engaged memiliki kesadaran dalam konteks bisnis dan bekerja dengan koleganya untuk meningkatkan kinerja dalam pekerjaan untuk keuntungan organisasi.

\section{Transformational Leadership}

Kepemimpinan transformasional adalah suatu proses dimana para pemimpin dan anggota saling menaikkan diri ke tingkat moralitas dan motivasi yang lebih tinggi. Pemimpin berupaya untuk mengubah perilaku anggotanya agar menjadi orang yang merasa mampu dan bermotivasi tinggi serta berupaya mencapai prestasi kerja yang tinggi dan berkualitas guna mencapai tujuan organisasi. Para anggota organisasi yang dipimpin secara transformasional akan merasakan adanya kepercayaan, kekaguman, kesetiaan dan hormat terhadap pimpinan, dan mereka termotivasi untuk melakukan pekerjaan dengan cara lebih baik dari yang diharapkan (Yulk, 1998).

\section{Meaning in Work}

Menurut Fryer dan Payne (1984) bekerja adalah kegiatan yang bermanfaat, ditentukan oleh tujuan yang pasti di luar kesenangan yang ditimbulkan oleh kinerjanya. Pekerjaan adalah pekerjaan individu didefinisikan oleh serangkaian kegiatan dihargai dalam sistem 
terorganisir secara ekonomi. Lebih dari itu Fryer dan Payne (1984), menjelaskan pekerjaan melibatkan hubungan pertukaran antara individu dan lembaga. Pekerjaan ini juga terkait dengan reward dalam bentuk gaji. Ini sering melibatkan persetujuan karyawan untuk memungkinkan orang lain untuk mendikte sifat pekerjaan dan bagaimana melakukan hal itu.

\section{Leader -Member Exchange (LMX)}

Kepemimpinan berkaitan dengan proses yang disengaja dari seseorang untuk menekankan pengaruhnya yang kuat terhadap orang lain untuk membimbing, membuat struktur, memfasilitasi aktifitas dan hubungan didalam kelompok atau organisasi (Yukl, 2005). Kepemimpinan merupakan kegiatan untuk mempengaruhi perilaku orang lain, atau seni mempengaruhi perilaku manusia baik perorangan maupun kelompok. Jadi dapat dikatakan bahwa kepemimpinan tidak harus dibatasi oleh aturan-aturan, tidak harus diikat dalam suatu organisasi tertentu, kepemimpinan bisa terjadi dimana saja, kapan saja asalkan seseorang menunjukkan kemampuannya mempengaruhi perilaku orang lain (Thoha, 2006).

Teori leader member exchange mampu menghasilkan pemaparan yang komprehensif dari bawahan sebagai bagian yang integral dari proses kepemimpinan (Johnson, 2009). Riggio (2008) menyatakan bahwa leader member exchange memiliki pendekatan yang berbeda dan berpendapat bahwa atasan yang efektif ditentukan oleh kualitas interaksi antara atasan dan bawahanbawahannya. Selain itu, dalam paradigma kepemimpinan yang lebih besar, teori leader member exchange telah berkembang menjadi salah satu pendekatan yang menarik dan berguna dalam mempelajari hubungan antara proses kepemimpinan dan hasil yang diharapkan (Johnson, 2009).

\section{Job Performance}

Menurut Stoner et al. (1996) kinerja (performance) adalah ukuran seberapa efisien dan efektif sebuah organisasi atau seorang manajer untuk mencapai tujuan yang memadai. Pengertian efisien sendiri adalah kemampuan untuk meminimalkan penggunaan sumber daya dalam mencapai tujuan organisasi, berarti melakukan dengan tepat, sedangkan efektivitas adalah kemampuan untuk menentukan tujuan yang memadai, berarti melakukan yang tepat.

Job performance menurut Yuki dan Waxley (1992) adalah berkenaan dengan apa yang dihasilkan seseorang, dari perilaku kinerjanya. Individu yang kinerjanya tinggi disebut sebagai orang yang produktif dan sebaliknya individu yang produktivitasnya rendah, dikatakan kinerjanya rendah.

\section{Hubungan antara transformational leadership pada work engagement}

Bass dalam Zanikham (2008) mendefinisikan kepemimpinan transformasional sebagai kemampuan pemimpin mengubah kemampuan kerja, motivasi kerja, dan pola kerja, dan nilainilai kerja yang dipersepsikan bawahan sehingga mereka lebih mampu mengoptimalkan kinerja untuk mencapai tujuan organisasi. Schaufeli, Salanova, González-Romá \& Bakker (2001) mendefinisikan work engagement sebagai sikap positif, memenuhi kondisi pekerjaan yang berhubungan dengan pikiran yang ditandai dengan semangat, dedikasi, dan penyerapan. Daripada keadaan sesaat dan spesifik, keterlibatan mengacu pada afektif-kognitif kondisi termotivasi dan menyebar luas yang tidak terfokus pada setiap objek tertentu, peristiwa, individu, atau perilaku. Kekuatan ditandai oleh tingginya tingkat energi dan ketahanan mental saat bekerja, kemauan seseorang untuk menginvestasikan usaha dalam pekerjaan, dan ketekunan bahkan dalam menghadapi kesulitan. Dedikasi mengacu menjadi sangat terlibat dalam pekerjaan seseorang dan mengalami rasa penting, antusiasme, inspirasi, kebanggaan, dan tantangan. Penyerapan ditandai dengan sepenuhnya terkonsentrasi dan bahagia dalam pekerjaan, dimana waktu berlalu 
dengan cepat dan memiliki kesulitan untuk memisahkan diri dari pekerjaan.

Dalam penelitiannya Gadhi (2013) menemukan dukungan bahwa transformational leadership berpengaruh pada work engagment. Selanjutnya, penelitian Susetyo (2015) mendapatkan temuan penelitian bahwa transformational leadership berpengaruh positif secara signifikan terhadap work engagement. lebih lanjut dijelaskan bahwa ternyata melalui pengaruh ideal, inspirasi motivasi, dan dorongan untuk berlaku inovatif mampu menggerakkan karyawan untuk bersedia lebih terlibat.

H1. Terdapat pengaruh signifikan transformational leaderhip pada work engagement.

\section{Hubungan antara transformational leadership dan meaning in work pada work engagement}

Menurut O'Leary

(2001)

kepemimpinan transformasional adalah gaya kepemimpinan yang digunakan oleh seseorang manajer bila ia ingin suatu kelompok melebarkan batas dan memiliki kinerja melampaui status quo atau mencapai serangkaian sasaran organisasi yang sepenuhnya baru. kepemimpinan transformasional pada prinsipnya memotivasi bawahan untuk berbuat lebih baik dari apa yang bisa dilakukan, dengan kata lain dapat meningkatkan kepercayaan atau keyakinan diri bawahan yang akan berpengaruh terhadap peningkatan kinerja. Menurut Rosso (2010) setelah menjelajahi berbagai sumber tentang meaning in work dapat dibagi menjadi tiga domain penelitian, fokus pada (1) values, (2) motivations, and (3) beliefs about work. Konsistensi antara manajer ' visi misi organisasi dan nilai-nilai inti dari bawahan mereka lebih mungkin untuk muncul. Dengan demikian, bawahan cenderung melihat pekerjaan yang lebih purposive, motivasi yang penting dan semuanya merupakan komponen integral dalam pekerjaan. Schaufeli dan Bakker (2006) mengasumsikan bahwa engagement dan burnout merupakan dua kutub berlawanan dari kontinum mengenai work related well-being, dengan burnout mewakili kutub negative dan engagement sebagai kutub positif.

Ghadi (2013) melakukan penelitian tentang keterkaitan antara transformational leadership dan meaning in work pada work engagement. peneletian tersebut mendapatkan temuan bahwa transformational leadership dan meaning in work berpengaruh signifikan pada work engagement. Dalam penelitian yang lain oleh Susetyo (2015) dengan variabel yang sama mendapatkan penelitian bahwa transformasional leadership dan meaning in work berpengaruh positif secara signifikan pada work engagement. Lebih mendalam dijelaskan bahwa karyawan yang mempunyai pemahaman tentang arti kerja lebih bersedia untuk terlibat. Hal ini dikarenakan keterlibatan karyawan bukan karena sebab keterpaksaan melainkan kesadaran dari dalam diri sendiri.

H2. Terdapat pengaruh signifikan transformational leadership dan meaning in work pada work engagement.

\section{Hubungan antara transformational leadership pada work engagement melalui mediasi meaning in work}

Bass et al. (2003) menjelaskan kemampuan pemimpin transformasional mengubah sistem nilai bawahan demi mencapai tujuan diperoleh dengan mengembangkan salah satu atau seluruh faktor yang merupakan dimensi kepemimpinan transformasional, yaitu : karisma (kemudian diubah menjadi pengaruh ideal atau idealized influence), inspirasi (inspirational motivation), pengembangan intelektual (intellectual stimulation), dan perhatian pribadi (individualized consideration). Faktor pendorong penting yang menyebabkan manusia bekerja adalah adanya kebutuhan yang harus dipenuhi. Aktivitas dalam kerja mengandung unsur suatu kegiatan sosial, menghasilkan sesuatu, dan pada akhirnya bertujuan untuk memenuhi kebutuhannya. Namun demikian di balik tujuan yang tidak langsung tersebut orang bekerja untuk mendapatkan imbalan yang berupa upah atau gaji dari hasil kerjanya itu. Jadi pada hakikatnya orang bekerja, tidak saja untuk mempertahankan kelangsungan hidupnya, tetapi juga bertujuan untuk mencapai taraf 
hidup yang lebih baik (As'ad, 2002). Vance (2006) keterlibatan kerja adalah hasil dari atribut pribadi seperti pengetahuan, keterampilam, kemampuan, tempramen, sikap dan sosial pengaturan dan praktik human resource yang secara langsung mempengaruhi komponen karyawan, proses dan konteks pekerjaan/kinerja karyawan.

Dalam suatu perusahaan meaning in work dapat terpenuhi ketika seorang karyawan menemukan apa yang dicari, menemukan pentingnya nilai dalam pekerjaan yang dilakukannya, dan menemukan harapan dalam pekerjaannya. $\mathrm{Hal}$ ini dapat mendorong terjadinya keterlibatan kerja. Dalam hal ini, meaning in work dapat diposisikan sebagai variabel mediasi antara kepemimpinan transformasional pada keterlibatan kerja. Di dalam mediasi terdapat dua penjelasan dimana mediasi dapat berpengaruh sebagian (partial) atau penuh (complete) Suhardi (2010). Kondisi mediasi penuh dapat terjadi ketika pengaruh kepemimpinan transformasional harus melalui meaning in work dalam mencapai keterlibatan kerja sedangkan kondisi mediasi sebagian dapat terjadi ketika kepemimpinan trasformasional dapat berpengaruh langsung pada keterlibatan kerja di lain sisi kepemimpinan transformasional juga dapat mempengaruhi keterlibatan kerja melalui meaning in work.

Hasil penelitian Gadhi (2013) menunjukan adanya dukungan signifikan mediasi meaning in work pada transformational leadership terhadap work engagment. Lebih Ianjut dijelaskan bahwa hasil penelitian Gadhi (2013) memperluas temuan penelitian seb elumnya dari Bakker et al. (2011) yang mengeklaim secara konseptual bahwa makna kerja dapat memediasi hubungan antara kepemimpinan transformasional dan keterlibatan kerja. Sedangkan Susetyo (2015) mengungkapkan dalam hasil penelitiannya bahwa meaning in work memiliki hubungan mediasi parsial dalam memediasi hubungan antara transformational leadership pada work engagement.

\section{H3. Meaning in Work memediasi pengaruh transformational leaderhip pada work engagement.}

\section{Hubungan antara leader member exchange pada job performance}

Riggio (2008) juga menjelaskan bahwa dalam leader member exchange yang tinggi, atasan memiliki pandangan yang positif menangani bawahannya dan bawahannya memiliki pandangan bahwa atasannya membantu dan mendukungnya sehingga terjalin komunikasi yang rutin antara atasan dan bawahannya. Menurut Mathis dan Jackson (2002) dalam pembahasan mengungkapkan bahwa kinerja karyawan berkaitan dengan beberapa faktor yang menyertai diantaranya : faktor kemampuan (ability) dan faktor motivasi.

Law dan Wang (2001) meneliti pengaruh antara leader member exchange pada job performance. Hasil penelitian Law dan Wang (2001) menunukan leader member exchange berpengaruh positif secara signifikan terhadap job performance. Pemimpin yang mempunyai kedekatan emosional dengan bawahannya akan lebih mudah menggerakkan bawahannya guna meningkatkan kinerjanya. Sedangkan pada penelitiannya Liang dan Crant (2010) juga mendapatkan temuan yang sama dimana leader member exchange berpengaruh signifikan terhadap job performance.

\section{H4. Terdapat pengaruh signifikan leader member exchange pada job performance.}

\section{Hubungan antara leader member exchange dan work engagement pada job performance}

Riggio (2008) menyatakan bahwa leader member exchange memiliki pendekatan yang berbeda dan berpendapat bahwa atasan yang efektif ditentukan oleh kualitas interaksi antara atasan dan bawahannya. Selain itu, dalam paradigma kepemimpinan yang lebih besar, teori leader member exchange telah berkembang menjadi salah satu pendekatan yang menarik dan berguna dalam mempelajari hubungan antara 
proses kepemimpinan dan hasil yang diharapkan. Luthans (2006) menjelaskan ada 3 situasi yang dapat meningkatkan keterlibatan kerja karyawan antara lain: a) perasaan : merasakan pengalaman bahwa tugas yang sedang dikerjakan adalah berharga, berguna, dan atau bernilai. b) rasa aman: mampu menunjukkan atau bekerja tanpa rasa takut atau memiliki konsekuensi negatif terhadap citra diri, status, dan atau karir. c) perasaan ketersediaan: individu merasa bahwa sumber-sumber yang memberikan kecukupan fisik personal, emosional, kognitif tersedia pada saat dib utuhkan.

Dalam Rotenberry (2011), Secara khusus, menjelaskan dampak dari keterlibatan kerja terhadap kinerja adalah negatif untuk orang Yahudi Israel namun positif bagi orang Arab Israel. Cohen (2006) menemukan bahwa keterlibatan kerja positif berpengaruh pada kinerja. Breevaart (2015) melakukan penelitian pengaruh antara leader member exchange dan work engagement pada job performance melalui mediasi work engagement, hasil penelitian menunukan adanya pengaruh signifikan leader member exchange dan work engagement pada job performance.

H5. Terdapat pengaruh signifikan leader member exchange dan work engagement pada job performance.

\section{Hubungan antara leader member exchange pada job performance melalui mediasi work engagement}

Ivancevich et al. (2006) mengatakan bahwa leader member exchange (LMX) adalah pendekatan yang mengenali adanya perilaku konsisten atasan kepada seluruh bawahannya. Yulk (1998) menjelaskan bagaimana atasan dan bawahan mengembangkan hubungan saling mempengaruhi satu sama lain dan menegoisasikan peran bawahan dalam satu organisasi. LMX tidak hanya melihat perilaku atasannya saja tetapi menekankan pada kualitas hubungan antara atasan dan bawahan.
Kuatnya pengaruh dan prilaku positif pimpinan akan meningkatkan job performance dalam perusahaan, ini tidak lepas dari pemahaman pekerja mengenai pekerjaannya dan kesesuaian harapan individu dengan harapan organisasi. Leader yang baik mampu merangsang motivasi bawahan sehingga meningkatkan performa kerja baik individu atau organisasi. Peningkatan performa kerja tidak akan terjadi tanpa adanya keterlibatan kerja dari tiap individu. Schaufeli, Salanova, González-Romá \& Bakker (2001) mendefinisikan work engagement sebagai sikap positif, memenuhi kondisi pekerjaan yang berhubungan dengan pikiran yang ditandai dengan semangat, dedikasi, dan penyerapan.

Work engagement selain dapat dijadikan variabel dependen dapat juga diposisikan sebagai variabel mediasi. Dalam mediasi terdapat dua penjelasan dimana mediasi dapat berpengaruh sebagian (partial) atau penuh (complete) Suhardi (2010). Kondisi mediasi penuh dapat terjadi ketika pengaruh LMX harus melalui keterlibatan kerja dalam mencapai kinerja sedangkan kondisi mediasi sebagian dapat terjadi ketika LMX dapat berpengaruh langsung pada kinerja di lain sisi LMX juga dapat mempengaruhi kinerja melalui keterlibatan kerja.

Pengembangan hipotesis ini diawali oleh Schaufeli et al. (2006) yang menyatakan bahwa LMX secara signifikan positif berpengaruh terhadap work engagement. hal ini dikarenakan semakin tinggi LMX maka akan meningkatkan tingkat dan jumlah orang yang terlibat dalam pekerjaan. Sementara itu, Breevaart (2015) dengan tegas dalam penelitiannya mendapatkan temuan penelitian bahwa work engagement memediasi LMX dengan job performance. Kedua penelitian tersebut saling memperkuat argumen dimana ada keterkaitan yang erat antara work engagement, LMX dan job performance.

H6. Work engagement memediasi pengaruh LMX pada job performance. 


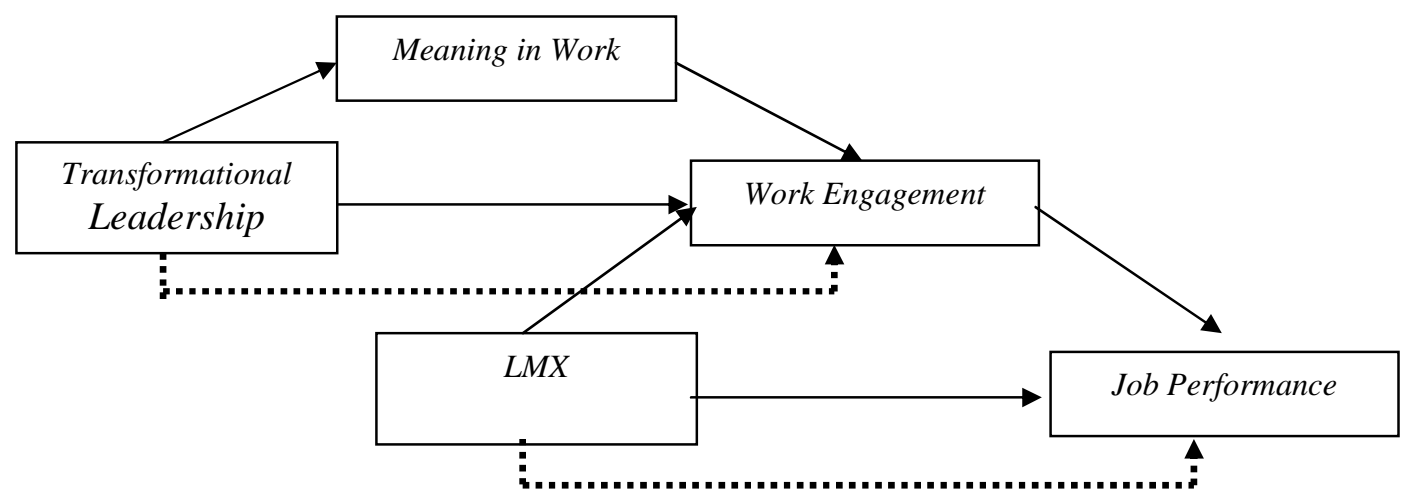

Sumber: Ghadi (2013) dan Breevaart (2015)

Gambar 1. Kerangka Berpikir

\section{METODE PENELITIAN}

Populasi, Sampel dan Teknik Sampling

Populasi dalam penelitian ini adalah seluruh karyawan PT. Kusumaputra Santosa yang jabatannya dibawah General Manager dan Manager. Hal ini dikarenakan PT. Kusumaputra Santosa merupakan perusahaan padat karya yang bergerak dibidang garment yang mana membutuhkan kepemimpinan yang baik dan keterlibatan kerja dari setiap karyawan untuk mencapai tujuan perusahaan. PT. Kusumaputra Santosa juga merupakan perusahaan yang telah lama berdiri sehingga sudah terbentuknya pengalaman kerja dari setiap karyawan dan ini sangat sesuai dengan criteria variabel yang akan diteliti. Pada penelitian ini penentuan sampel menggunakan tabel Krecjie dengan signifikansi 0,05 , dengan $\mathrm{N}$ sebesar 550 didapatkan sampel 213 responden. Dalam penelitian ini, peneliti menerapkan metode proportionate stratified sampling sebagai acuan untuk menentukan responden. Responden dipilih berdasarkan level jabatan secara proporsional. Maksudnya adalah setiap level jabatan dipilih berdasarkan rumus perhitungan jumlah level jabatan dibagi total populasi kemudian dikalikan total sampel. Selanjutnya dari hasil perhitungan tersebut dipilih secara acak untuk menjadi responden.

\section{Definisi Operasional dan Pengukuran Variabel}

1. Transformational Leadership

Bass et al. (2003) menjelaskan kemampuan pemimpin transformasional mengubah sistem nilai bawahan demi mencapai tujuan diperoleh dengan mengembangkan salah satu atau seluruh faktor yang merupakan dimensi kepemimpinan transformasional, yaitu: karisma kemudian diubah menjadi (pengaruh ideal atau idealized influence), inspirasi (inspirational motivation), pengembangan intelektual (intellectual stimulation), dan perhatian pribadi (individualized consideration). Variabel Transformational leadership diukur dengan skala likert mulai poin 1 yang menyatakan sangat tidak setuju sampai poin 5 yang menyatakan sangat setuju. Variabel Transformational leadership diukur dengan menggunakan 20 item pernyataan yang diadaptasi dari penelitian Zhu (2009).

\section{Meaning in Work}

Rosso (2010) mengidentifikasi empat sumber utama meaning in work adalah diri, dan mencakup value, motivation, dan belief bahwa karyawan menarik untuk memahami makna dari pekerjaan mereka. Variabel meaning in work diukur dengan skala likert mulai poin 1 yang menyatakan sangat tidak setuju sampai poin 5 yang menyatakan sangat setuju. Variabel meaning in work diukur dengan 
menggunakan 6 item pernyataan yang diadaptasi dari penelitian G hadi (2013).

3. Work engagement Jones dan Harter (2005) mendefinisikan keterlibatan kerja sebagai "keterlibatan individu dan kepuasan dengan, serta antusiasme untuk pekerjaan mereka", efinisi ini erat kaitannya dengan konseptualisasi keterlibatan kognitif dan emosional. Kahn (1990) membahas tiga kondisi psikologis, termasuk kebermaknaan psikologis, keamanan psikologis, dan ketersediaan psikologis, yang dianggap anteseden untuk keterlibatan pribadi. Kebermaknaan psikologis merupakan perasaan positif yang orang dapatkan dari investasi fisik, kognitif, dan energi emosional dalam tugas-tugas kerja. Keamanan psikologis mengacu pada sejauh bahwa individu merasa mereka terpercaya dan dapat mempercayai orang lain di sekitar mereka. Ketersediaan psikologis mengacu pada keyakinan individu bahwa mereka memiliki sumber daya yang diperlukan, termasuk fisik, sumber daya emosi, dan kognitif, untuk melibatkan diri di tempat kerja. Variabel Work engagement diukur dengan skala likert mulai poin 1 yang menyatakan tidak setuju sampai poin 5 yang menyatakan sangat setuju. Variabel Work engagement diukur dengan menggunakan 17 item pernyataan yang diadaptasi dari penelitian G hadi (2013).

4. Leader Memeber Exchange

Menurut Griffin (2004) model hubungan atasan dan bawahan (leader member exchange) (LMX) yang dikembangkan oleh Geoge Graen dan Fred Dansereau, menekankan pentingnya hubungan variatif antara atasan dengan masing-masing bawahanya. Yulk (1998) menjelaskan bagaimana atasan dan bawahan mengembangkan hubungan saling mempengaruhi satu sama lain dan menegoisasikan peran bawahan dalam satu organisasi. LMX tidak hanya melihat perilaku atasannya saja tetapi menekankan pada kualitas hubungan antara atasan dan bawahan. Ivancevich et al. (2006) mengatakan bahwa leader member exchange (LMX) adalah pendekatan yang mengenali tidak adanya konsisten perilaku atasan kepada seluruh bawahannya.
Atasan membina ikatan dan hubungan pribadi terhadap masing - masing bawahannya. Variabel leader member exchange diukur dengan skala likert mulai poin 1 yang menyatakan tidak setuju sampai poin 5 yang menyatakan sangat setuju. Variabel bahwa leader member exchange diukur dengan menggunakan 12 item pernyataan yang diadaptasi dari penelitian Breevaart (2015).

5. Job Performance

Menurut Stoner et al. (1996) kinerja (performance) adalah ukuran seberapa efisien dan efektif sebuah organisasi atau seorang manajer untuk mencapai tujuan yang memadai. Pengertian efisien sendiri adalah kemampuan untuk meminimalkan penggunaan sumber daya dalam mencapai tujuan organisasi, berarti melakukan dengan tepat, sedangkan efektivitas adalah kemampuan untuk menentukan tujuan yang memadai, berarti melakukan yang tepat. Variabel job performance diukur dengan skala likert mulai poin 1 yang menyatakan tidak setuju sampai poin 5 yang menyatakan sangat setuju. Variabel bahwa job performance diukur dengan menggunakan 9 item pernyataan yang diadaptasi dari penelitian Breevaart, (2015).

\section{HASI L DAN PEMBAHASAN}

\section{Analisis Deskriptif}

\section{Karakteristik Responden}

Jumlah dari responden sebanyak 213 orang yang terdiri dari 105 orang atau 49,3\% adalah laki-laki dan 108 orang atau $50,7 \%$. Jumlah responden prosentasenya relatif seimbang antara laki-laki dan perempuan, hal ini dikarenakan pada level operator (divisi produksi) pekerjaannya bisa dilakukan baik laki-laki maupun perempuan. Sehingga kehadiran karyawan perempuan dalam hal ini, tidak mengganggu produktivitas perusahaan secara keseluruhan.

Karyawan memiliki tingkat pendidikan SMP yaitu sebesar $25,3 \%$, SMA sebesar $68,1 \%$, Diploma sebesar 3,8\%, Sarjana sebesar 2,8\% dan pascasarjana sebesar $0 \%$. Sebagian besar karyawan memiliki tingkat pendidikan SMA, dikarenakan PT 
Kusumaputra Santosa adalah perusahaan dibidang tekstil yang termasuk jenis perusahaan padat karya. Usia responden paling banyak berada di range 41-50 tahun sebanyak $55,9 \%$, kemudian range 21-30 tahun sebanyak 33,3\%. Hal ini menunjukkan PT Kusumaputra Santosa menempatkan usia produktif sebagai bahan pertimbangan utama dalam rekruitmen karyawan. Sebagai perusahaan padat karya, PT Kusumaputra Santosa menempatkan karyawan paling banyak di sektor operator atau orang bersentuhan langsung dengan produksi. Hal ini bisa dilihat dengan jumlahnya sebanyak $67,8 \%$.

\section{Tanggapan Responden}

Pengumpulan data dilakukan dengan memberikan kuesioner kepada responden untuk dijawab dengan model skala likert. terdapat 5 variabel yang telah dijawab oleh responden yaitu Transformational Leadership, Meaning in Work, Leader Member Exchange, Job Performance dan W ork Engagement.

Pada variabel Transformational ini terdiri dari 4 indikator yaitu idealized influence, Inspirational motivation, Intellectual stimulation dan Individualized consideration. Kemudian dari indikator tersebut dijadikan dasar untuk membuat pernyataan. Pada variabel ini ada 6 pernyataan yang harus dijawab oleh responden, guna mengetahui persepsi responden tentang Transformational Leadership. Nilai rata-rata dari pernyataan 1 sebesar 5, pernyataan 2 sebesar 4,22, pernyataan 3 sebesar 3,9 , pernyataan 4 sebesar 3,9, pernyataan 5 sebesar 3,8, pernyataan 6 sebesar 3,8. Berdasarkan penjelasan tersebut dapat diinterpretasikan bahwa jawaban responden cenderung berada di level "setuju". Hal ini menunjukkan bahwa variabel Transformational Leadership di PT Kusumaputra Santosa ikut memberikan warna, dalam keberlangsungan perusahaan dalam mencapai target yang ditentukan.

Berdasarkan tanggapan responden tentang Transformational Leadership menunjukkan bahwa variabel Meaning in Work yang terdapat pernyataan 1 sampai 6 , sebagian responden menjawab "setuju" dengan prosentase sebagai berikut: pernyataan 1 sebesar $63,38 \%$, pernyataan 2 sebesar $53,52 \%$, pernyataan 3 sebesar $61,97 \%$, pernyataan 4 sebesar $17,84 \%$, pernyataan 5 sebesar $63,38 \%$, pernyataan 6 sebesar $65,73 \%$ dan pernyataan 7 sebesar $57,7 \%$. Sedangkan rata-rata adalah pernyataan 1 sama dengan 4,19\%, pernyataan 2 sama dengan 4,05\%, pernyataan 3 sama dengan 4 , pernyataan 4 sama dengan $4,03 \%$, pernyataan 5 sama dengan $4,23 \%$ dan pernyataa

Pada variabel Work Engagement ini terdapat 3 indikator dan 17 pernyataan. Rata rata jawaban responden diangka $3,8 \%$ sampai 3,9\%, sedangkan prosentase terbanyak masih sama dengan variabelvariabel sebelumnya yaitu sebagian besar responden menjawab "setuju" disetiap pernyataannya.

Pada variabel Leader Member Exchange ini terdapat 3 indikator dan 12 pernyataan. Rata rata jawaban responden diangka $3,4 \%$ sampai $4,19 \%$, sedangkan prosentase terbanyak masih sama dengan variabel-variabel sebelumnya yaitu sebagian besar responden menjawab "sangat setuju" disetiap pernyataannya.

Selanjutnya adalah tanggapan responden tentang variabel job performance. Variabel ini ada 3 pernyataan yang harus dijawab responden. Dari hasil pengumpulan data, didapatkan hasil bahwa rata-rata jawaban responden pada pernyataan 1 sampai 3 masing-masing sebesar 4,19\%, 4,08, dan 3,64 . Secara lebih detail, semua responden menjawab "sangat setuju". 


\section{Deskripsi Data Penelitian}

Tabel 1. Ringkasan Deskripsi Data Penelitian

\begin{tabular}{|l|l|c|c|c|c|c|}
\hline No & \multicolumn{1}{|c|}{ Variabel } & N & $\begin{array}{c}\text { St } \\
\text { Deviasi }\end{array}$ & Mean & Min & Maks \\
\hline 1 & $\begin{array}{l}\text { Transformational } \\
\text { Leadership }\end{array}$ & 213 & 8,510 & 60,91 & 37 & 80 \\
\hline 2 & Meaning in Work & 213 & 2,695 & 24,52 & 16 & 30 \\
\hline 3 & Leader Member Exchange & 213 & 2,923 & 17,63 & 13 & 25 \\
\hline 4 & Work Engagement & 213 & 6,430 & 41,76 & 24 & 55 \\
\hline 5 & JobPerformance & 213 & 1,510 & 16,91 & 12 & 20 \\
\hline
\end{tabular}

Sumber: Data primer diolah, 2015

Variabel Transformational Leadership terdiri dari 4 indikator dan 20 pernyataan. Setelah dilakukan pengolahan data dihasilkan deskripsi data N sebanyak 213, St Deviasi sebesar 8,510, Mean sebesar 60,91 , Minimal sebesar 37 dan Maksimal sebesar 80. Variabel Meaning in Work terdiri dari 6 pernyataan. Setelah dilakukan pengolahan data deskriptif dihasilkan N sebesar 213, St Deviasi sebesar 2,695, Mean sebesar 24,52, Minimal sebesar 16 dan maksimal sebesar 30.Variabel Leader Member Exchange terdiri dari 12 pernyataan. Dari hasil pengolahan data, didapatkan deskripsi data sebagai berikut: N sebesar 213, St Deviasi sebesar 2,923, Mean sebesar 17,63, Minimal sebesar 13 dan Maksimal sebesar 30.Variabel Work Engagement terdiri dari 3 indikator dan 5 pernyataan, dengan deskripsi data sebagai berikut: $\mathrm{N}$ sebesar 213, St Deviasi sebesar 6,430, Mean sebesar 41,76, Minimal sebesar 24 dan Maksimal sebesar 55.Variabel Job Performance terdiri dari 3 pernyataan. Setelah dilakukan pengolahan data deskriptif dihasilkan N sebesar 213, St Deviasi sebesar 1,510, Mean sebesar 16,91, Minimal sebesar 12 dan maksimal sebesar 20.

\section{Uji Instrumen Penelitian}

\section{Uji Validitas}

Uji validitas pada penelitian ini menggunakan teknik Confirmatory Factor Analysis (CFA). Analisis faktor pada variabel transformational leadership yang terdiri dari 4 faktor dengan 20 pernyataan mempunyai KMO 0,848 dengan signifikansi $0,000<0,05$ dan MSA pada
Anti Image Matrices semua nilainya $>0,5$. Hal ini dapat diartikan bahwa analisis faktor untuk item pernyataan variabel transformational leadership masuk dalam kategori feasible.

Berdasarkan data yang diolah dijelaskan bahwa 20 pernyataan yang tertuang dikuesioner dikelompokkan pada 4 faktor. Pengolahan data dilakukan dengan SPSS 22, untuk menghitung analisis faktor. Setelah dikalkulasi dan dirotasi dengan metode varimax untuk menentukan 4 faktor yang akan dibentuk, kemudian dihasilkan data dimana Idealized influence mengelompok di faktor 3 dengan nilai semuanya $>0,5$, Inspirational motivation mengelompok di faktor 4 dengan nilai $>0,5$ di nomer 1,2 dan 3 sedangkan nomer 4 dan 5 nilainya $<0,5$ atau tidak valid, lintellectual stimulation mengelompok di faktor 1 dengan nilai semuanya $>0,5$, dan Individualized consideration mengelompok di faktor 4 dengan nilai semuanya $>0,5$ kecuali di nomer 2 sehingga dari indikator ini ada 1 yang tidak valid. Dengan demikian, dapat dikatakan bahwa data variabel tansformationalleadership dinyatakan valid sebaanyak 17 pernyataan dan dapat dilakukan proses pengolahan data berikutnya.

Variabel meaning in work terdapat 6 pernyataan di dalam kuesionernya. Dari 6 pernyataan tersebut hanya dikelompokkan 1 faktor. Berdasarkan kalkulasi analisis faktor didapatkan data bahwa nilai KMO sebesar 0,835dengan signifikansi 0,000 < 0,05 dengan nilai Anti Image Matrices> 0,5. Sementara itu, data analisis faktor menunjukkan bahwa semua pernyataan nilainya $>0,5$. Dengan demikian dapat 
dikatakan bahwa semua pernyataan dalam kuesioner pada variabel meaning in work adalah valid.

Nilai KMO pada analisis faktor dari leader member exchange adalah 0,844 dengan signifikansi $0,000<0,05$ dan nilai Anti Image Matrices-nya di atas 0,5. Sementara itu, data analisis faktor menunjukkan bahwa semua pernyataan nilainya $>0,5$. Dengan demikian dapat dikatakan bahwa semua pernyataan dalam kuesioner pada variabel leader member exchange adalah valid.

Nilai KMO pada analisis faktor dari work engagement adalah 0,744 dengan signifikansi $0,000<0,05$ dan nilai Anti Image Matrices-nya di atas 0,5. Sementara itu, dari proses analisis faktor setelah dilakukan rotasi tersebut didapatkan beberapa pernyataan dalam kuesioner yang tidak valid diantaranya vigor 4 , vigor 5, vigor 6, dedication 5, absorption1 dan absorption 3. Dengan demikian, pada variabel work engagement ini pernyataan yang digunakan pada tahap selanjutnya adalah 11 pernyataan dari 17 pernyataan sebelumnya yang terdiri dari 3 pernyataan dari vigor, 4 pernyataan dari dedication dan 4 pernyataan dari absorption.

Variabel job performance terdapat 3 pernyataan di dalam kuesionernya. Berdasarkan hasil analisis faktor menggunakan SPSS 22 didapatkan nilai KMO sebesar 0,865 dengan signifikansi $0,000<0,05$ dan Anti Image Matrices $>0,5$. Berdasarkan tampilan data pada Tabel
4.15 di atas, dari 3 pernyataan mempunyai nilai faktor $>0,5$ semuanya. Dengan demikian kuesioner pada variabel job performance dinyatakan valid dan dapat digunakan pada tahap selanjutnya.

\section{Uji Reliabilitas}

Berdasarkan Uji Reliabilitas dapat dijelaskan bahwa nilai Cronbach Alpha Transformational Leadership adalah 0,879 masuk kategori baik, Meaning in Work 0,807 kategori baik, Leader Member Exchange 0,782 dapat diterima, Work Engagement 0,802 dan Job performance sebesar 0,851 termasuk baik, maka data tersebut dinyatakan reliabel. Dengan demikian, kuesioner ini dapat digunakan untuk melakukan uji hipotesis.

\section{Uji Asumsi Model}

\section{a. Uji Normalitas}

Berdasarkan

Normalitasmenunjukkan bahwa nilai Z tidak melebihi (-2 sampai 2). Dengan demikian, dapat dikatakan bahwa uji normalitas ini menjelaskan bahwa data terdistribusi normal.

\section{b. Uji Heteroskedastisitas}

Hasil pengolahan data dengan menggunakan Uji Glejser menunjukkan bahwa signifikansinya $>0,05$. Dengan demikian dapat dibuat pernyataan bahwa data penelitian tidak terjadi heteroskedastisitas dan dapat dilanjutkan pada proses selanjutnya.

\section{Uji Hipotesis}

Tabel 2. Hasil Analisis Data Transformational Leadership pada Work Engagement

\begin{tabular}{|l|r|r|r|}
\hline \multirow{2}{*}{ Konstanta } & \multicolumn{3}{|c|}{ Work Engagement } \\
\cline { 2 - 4 } Transformational Leadership & Koefisien & $\begin{array}{c}\text { Nilai Uji } \\
\mathbf{t}\end{array}$ & \multicolumn{1}{c|}{ Sig } \\
\cline { 2 - 4 } F & -2.220 & -2.356 & .019 \\
Sig. & .722 & 47.116 & .000 \\
R & \multicolumn{3}{|c}{} \\
R2 & & & 2219.935 \\
R2 adj & & & $.000^{\mathrm{b}}$ \\
& & $.956^{\mathrm{a}}$ \\
\end{tabular}

Sumber: Data diolah, 2015 
Tabel 3. Hasil Analisis Data Transformational Leadership dan meaning in work pada Work Engagement

\begin{tabular}{|c|c|c|c|}
\hline \multirow{5}{*}{$\begin{array}{l}\text { Konstanta } \\
\text { Transformational Leadership } \\
\text { Meaning in Work }\end{array}$} & \multicolumn{3}{|c|}{ Work Engagement } \\
\hline & Koefisien & $\underset{t}{\text { Nilai Uji }}$ & Sig \\
\hline & -3.207 & -3.065 & .002 \\
\hline & .703 & 39.954 & .000 \\
\hline & .089 & 2.101 & .037 \\
\hline $\mathbf{F}$ & & & 1130.137 \\
\hline Sig. & & & $.000^{\mathrm{b}}$ \\
\hline & & & $.957^{\mathrm{a}}$ \\
\hline & & & .915 \\
\hline R2 adj & & & .914 \\
\hline
\end{tabular}

Sumber: Data diolah, 2015

Tabel 4. Hasil Analisis Data Mediasi Meaning in Work pada Transformational Leadership terhadap Work Engagement

\begin{tabular}{|c|l|c|c|c|}
\hline No & \multicolumn{1}{|c|}{ Variabel } & $\begin{array}{c}\text { Pengaruh } \\
\text { Langsung }\end{array}$ & $\begin{array}{c}\text { Pengaruh } \\
\text { Tidak } \\
\text { langsung }\end{array}$ & $\begin{array}{c}\text { Pengaruh } \\
\text { Total }\end{array}$ \\
\hline 1 & $\begin{array}{l}\text { Transformational Leadership } \ddagger \\
\text { Work Engagement }\end{array}$ & 0.722 & - & - \\
\hline 2 & $\begin{array}{l}\text { Transformational Leadership } \ddagger \\
\text { Meaning in Work } ¥ \text { Work } \\
\text { Engagement }\end{array}$ & - & $\begin{array}{l}0.703 X \\
0.089 \\
=0,062\end{array}$ & $\begin{array}{l}0,722+0,06 \\
=0,784\end{array}$ \\
\hline
\end{tabular}

Sumber: Data diolah, 2015

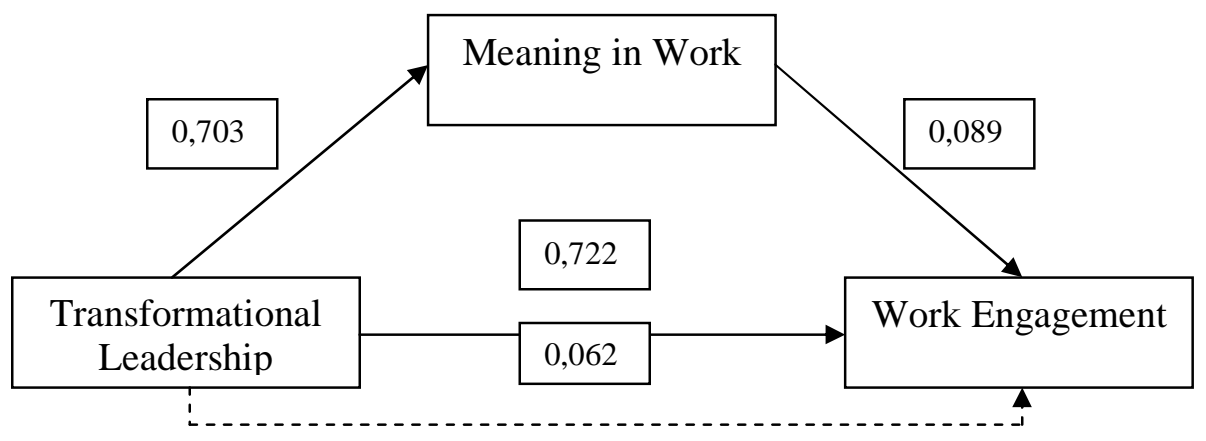

Gambar 4.1 Mediasi Meaning in Work pada Transformational Leadership terhadap Work Engagement

Keterangan:

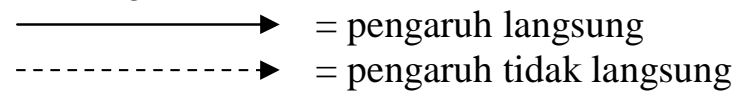


Tabel 5. Hasil Analisis Data Leader Member Exchange (LMX) pada job performance

\begin{tabular}{|c|c|c|c|}
\hline \multirow[b]{3}{*}{$\begin{array}{l}\text { Konstanta } \\
\text { LMX }\end{array}$} & \multicolumn{3}{|c|}{ Job Performance } \\
\hline & Koefisien & $\underset{t}{\text { Nilai Uji }}$ & Sig \\
\hline & $\begin{array}{r}7.172 \\
.792 \\
\end{array}$ & $\begin{array}{r}3.399 \\
13.968\end{array}$ & $\begin{array}{l}0.001 \\
0.000\end{array}$ \\
\hline $\mathbf{F}$ & & & 195.100 \\
\hline Sig. & & & $0.000^{b}$ \\
\hline & & & $0.693^{\mathrm{a}}$ \\
\hline & & & 0.480 \\
\hline R2 adj & & & 0.478 \\
\hline
\end{tabular}

Sumber: Data diolah, 2015

Tabel 6. Hasil Analisis Data Leader member exchange (LMX) dan work engagement pada job performance

\begin{tabular}{|c|c|c|c|}
\hline & \multicolumn{3}{|c|}{ Job Performance } \\
\hline & Koefisien & $\underset{t}{\text { Nilai Uji }}$ & Sig \\
\hline Konstanta & 2.852 & 1.733 & .085 \\
\hline Leader Member Exchange (LMX) & .480 & 9.591 & .000 \\
\hline Work Engagement & .380 & 12.378 & .000 \\
\hline $\mathbf{F}$ & & & 244.535 \\
\hline Sig. & & & $.000^{\mathrm{b}}$ \\
\hline $\mathbf{R}$ & & & $.836^{\mathrm{a}}$ \\
\hline $\mathbf{R 2}$ & & & .700 \\
\hline R2 adj & & & 697 \\
\hline
\end{tabular}

Sumber: Data diolah, 2015

Tabel 7. Hasil Analisis Data Mediasi Work Engagement pada Leader Member Exchange (LMX) terhadap Job Performance

\begin{tabular}{|c|c|c|c|c|}
\hline No & Variabel & $\begin{array}{l}\text { Pengaruh } \\
\text { Langsung }\end{array}$ & $\begin{array}{c}\text { Pengaruh } \\
\text { Tidak } \\
\text { langsung }\end{array}$ & $\begin{array}{c}\text { Pengaruh } \\
\text { Total }\end{array}$ \\
\hline 1 & $\begin{array}{l}\text { Leader Member Exchange } \\
\text { (LMX)‡ Job Performance }\end{array}$ & 0.792 & - & - \\
\hline 2 & $\begin{array}{l}\text { Leader Member Exchange } \\
(\text { LMX) } \neq \text { Work } \\
\text { Engagement } ¥ \text { Job Performance }\end{array}$ & - & $\begin{array}{l}0.480 \times 0.38 \\
0 \\
=0,182\end{array}$ & $\begin{array}{l}0,792+0,18 \\
2 \\
=0,974\end{array}$ \\
\hline
\end{tabular}

Sumber: Data diolah, 2015 


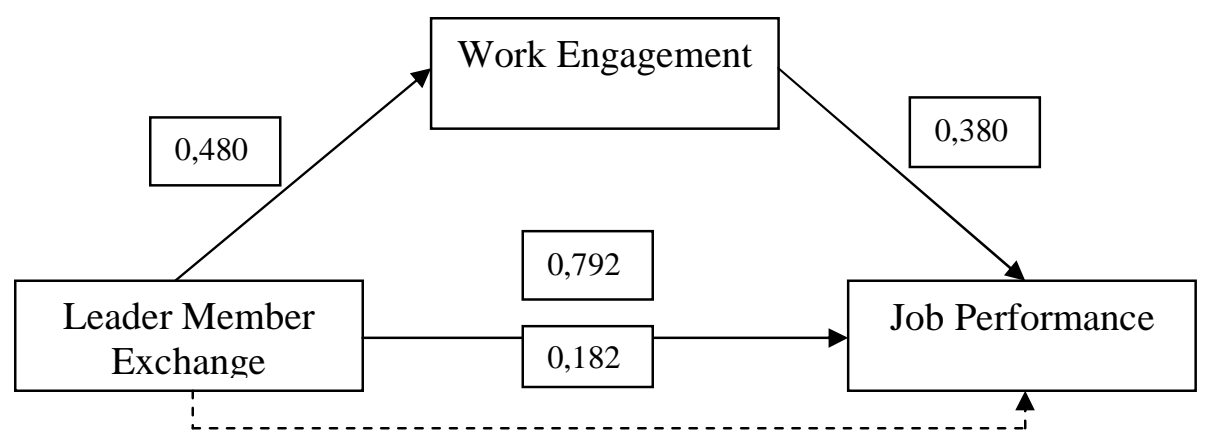

Gambar 4.2 Mediasi Work Engagement pada Leader Member Exchange terhadap Job Performance

Keterangan:

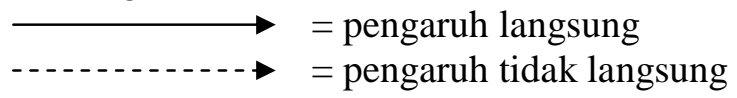

\section{PEMBAHASAN}

\section{Pengaruh transformational leadership pada work engagement}

Hasil Penelitian secara statistik telah menunjukkan bahwa transformational leadership memberikan pengaruh positif terhadap work engagement. Talent management di perusahaan berjalan dengan baik, hal ini memunculkan banyak pemimpin yang berasal dari intern perusahaan yang pengab diannya rata-rata lebih 10 tahun. Dengan loyatitas yang tinggi dan adanya kebersamaan yang dibangun lama antar karyawan, pemimpin akan lebih mudah untuk mendistribusikan pengaruhnya. Budaya berani mencoba dan jangan takut gagal juga terlihat dalam proses kerja sehari-hari, sehingga karyawan berani terlibat lebih untuk kerja secara inovatif dan kreatif. Di samping itu, dengan segudang pengalamannya, pemimpin di perusahaan sering menginspirasi bawahannya dalam hal memberikan contoh yang benar dalam aktivitas kerjanya. Hal ini akan meningkatkan kepercayaan bawahan bahwa atasan selalu hadir dalam segala situasi untuk mengendalikan dan mengontrol pada setiap pekerjaan. Secara teoritis Luthans (2006) menjelaskan bahwa ada tiga keadaan psikologis yang dapat meningkatkan kemungkinan keterlibatan kerja dalam pekerjaan mereka. Kondisikondisi tersebut antara lain adalah: a) perasaan berarti: merasakan pengalaman bahwa tugas yang sedang dikerjakan adalah berharga, berguna, dan atau bernilai. b) rasa aman: mampu menunjukkan atau bekerja tanpa rasa takut atau memiliki konsekuensi negatif terhadap citra diri, status, dan atau karir. c) perasaan ketersediaan: individu merasa bahwa sumber-sumber yang memberikan kecukupan fisik personal, emosional, kognitif tersedia pada saat dibutuhkan.

Sementara itu, hasil hipotesis ini senada dengan hasil penelitian Ghadi (2013) yang mengatakan transformational leadership berpengaruh positif terhadap work engagement. Di samping itu, hasil penelitian ini juga sejalan dengan hasil penelitiannya Susetyo (2015) yang mendapatkan temuan penelitian bahwa transformational leadership berpengaruh positif secara signifikan terhadap work engagement.

\section{Pengaruh transformational leadership dan meaning in work pada work engagement}

Hasil penelitian ini menjelaskan bahwa transformational leadership dan meaning in work berpengaruh positif secara signifikan pada work engagement. Atasan yang mempunyai gaya 
kepemimpinan transformasional akan menggunakan pengaruh, inspirasi, intelektual dan mendorong berbuat lebih untuk mengoptimalkan sumber daya guna mencapai tujuan organisasi. Sedangkan meaning in work memberikan ruang bagi pribadi untuk memahami lebih apa itu kerja. Karyawan yang mengartikan kerja tidak hanya sekedar mencari uang, biasanya akan mempunyai kesadaran lebih untuk terlibat. Karena selain uang, makna kerja meliputi nilai-nilai, motivasi dan percaya bahwa pekerjaan yang dilakukan akan dapat membuat hidupnya lebih bermakna. Nilai-nilai tersebut yang akan mendorong individu bersedia terlibat dengan kesadaran tinggi. Di tambahkan oleh Bass dalam Zanikham (2008) yang menjelaskan bahwa kepemimpinan Transformasional adalah kemampuan pemimpin mengubah kemampuan kerja, motivasi kerja, dan pola kerja, dan nilai-nilai kerja yang dipersepsikan bawahan sehingga mereka lebih mampu mengoptimalkan kinerja untuk mencapai tujuan organisasi. Sedangkan menurut Danim (2005: 54) kepemimpinan transformasional adalah kemampuan seseorang pemimpin dalam bekerja dengan dan/atau melalui orang lain untuk mentransformasikan, secara optimal sumber daya organisasi dalam rangka mencapai tujuan yang bermakna sesuai dengan target capaian yang telah ditetapkan.

Hasil penelitian ini senada dengan penelitian Ghadi (2013) yang menjelaskan bahwa terdapat positif yang signifikan antara transformational leadership dan meaning in work pada work engagement. Dalam penelitian yang lain, Susetyo (2015) juga mendapatkan temuan yang sama bahwa transformasional leadership dan meaning in work berpengaruh positif secara signifikan pada work engagement.

Pengaruh mediasi meaning in work
yang memediasi transformational Berdasarkan perhitungan analisis jalur,pengaruh langsung transformational leadership pada work engagement ternyata lebih besar dibandingkan pengaruh tidak langsung variabel transformational

leadership pada work engagement melalui variabel mediasi meaning in work. Karena hasilnya masih signifikan maka dapat disimpulkan bahwa transformational leadership berpengaruh signifikan positif terhadap work engagement melalui meaning in work sebagai variabel mediasi sebagian (partial mediation). Kepemimpinan transformasional dipercaya mampu menggerakkan karyawan untuk terlibat. Keterlibatan karyawan secara tidak langsung dipengaruhi oleh bagaimana karyawan memaknai pekerjaannya. Keteladanan atasan memberikan inspirasi lebih bagi karyawan baik dalam pekerjaan maupun dalam kehidupan. Kebersamaan yang dibangun sejak lama melalui budaya makan siang, shalat jumat bersama dan berolahraga bersama akan memberikan ruang bawahan untuk berinteraksi secara informal situasi ini dapat dijadikan peluang bagi pimpinan dalam memotivasi karyawan, menanamkan rasa percaya pada karyawan dengan kondisi santai. Dengan demikian, ada rasa tanggungjawab lebih dari bawahan untuk menyelesaikan setiap pekerjaan yang menjadi tugasnya dikarenakan sudah ada kepercayaan dan kedekatan yang mendalam dengan atasannya. Ditambahkan Robbins (2003) yang mengatakan keterlibatan kerja yaitu derajat dimana orang dikenal dari pekerjaannya, partisipasi aktif di dalamnya, dan menganggap prestasinya penting untuk harga diri. Sedangkan Luthans (2006) mendefinisikan bahwa keterlibatan kerja terjadi jika anggota organisasi menempatkan dirinya dalam peran fisik, kognitif, dan emosional selama kinerja peran (pekerjaan).

Seorang pemimpin dengan gaya transformasional dapat mempengaruhi bawahannya untuk terlibat dalam pekerjaan secara langsung, hal ini dikarenakan kemampuan dalam memotivasi dan menanamkan pengaruh terhadap bawahan. Di lain sisi pemimpin dengan gaya kepemimpinan transformasional dapat menanamkan pemahaman akan pekerjaan dalam 
membentuk keterlibatan kerja, hal ini dikarenakan pemimpin dengan gaya transformasional dapat menanamkan rasa tanggung jawab pada pekerjaan, memberikan motivasi pada bawahan, dan menanmkan pentingnya dalam pekerjaan, kondisi ini akan memberikan pengaruh pada keterlibatan karyawan karena dengan kombinasi yang ada karyawan akan merasa bersedia terjun total, semangat dan merasa percaya diri mampu menangani tuntutan pekerjaan.

Hasil penelitian ini berbanding lurus dengan temuan penelitian Gadhi (2013) yang menjelaskan bahwa terdapat dukungan yang signifikan mediasi meaning in work pada transformational leadership terhadap work engagment. Sedangkan Susetyo (2015) menjelaskan bahwa meaning in work memiliki hubungan mediasi parsial dalam memediasi hubungan antara transformational leadership pada work engagement.

\section{Pengaruh leader member exchange pada job performance}

Hasil penelitian ini menjelaskan bahwa terdapat pengaruh positif yang signifikan antara leader member exchange pada job performance. Kepemimpinan erat kaitannya dengan atasan, bawahan dan situasi. Ketiga hal tersebut terjalin jika ada interaksi antara atasan dengan bawahan untuk menjawab berbagai macam situsasi dalam pekerjaan. Dengan kata lain, leader member exchange yang berkualitas tinggi akan mendorong karyawan dalam meningkatkan kinerjanya.

Riggio (2008) juga menjelaskan bahwa dalam leader member exchange yang tinggi, atasan memiliki pandangan yang positif dalam menangani bawahannya dan bawahannya memiliki pandangan bahwa atasannya membantu dan mendukungnya. Dalam hubungan ini terdapat komunikasi yang rutin antara atasan dan bawahannya. Dalam konteks situasi di perusahaan, dengan budaya kebersamaannya yang tinggi, secara tidak langsung menghasilkan rasa saling percaya dan menghargai baik rekan kerja sejawat maupun dengan atasannya. Dengan demikian tanggung jawab tugas dan tanggungjawab individu karyawan bisa didorong untuk kinerja lebih baik, melalui kedekatan amosional antara atasan dengan bawahan.

Penelitian ini sejalan dengan temuan penelitiannya Law dan Wang (2001) yang mengatakan bahwa leader member exchange berpengaruh positif secara signifikan terhadap job performance. Pemimpin yang mempunyai kedekatan emosional dengan bawahannya akan lebih mudah menggerakkan bawahannya guna meningkatkan kinerjanya. Penelitiannya Liang dan Crant (2010) juga mendapatkan temuan yang senada dimana leader member exchange berpengaruh signifikan terhadap job performance.

\section{Pengaruh leader member exchange dan work engagement pada job performance}

Hasil penelitian ini menjelaskan bahwa terdapat pengaruh positif yang signifikan antara leader member exchange dan work engagement pada job performance. Keterlibatan karyawan merupakan indikator bahwa job performance nya juga tinggi. Karena kinerja karyawan ditentukan oleh proses yang baik dan hasil yang sesuai target. Sehingga secara keseluruhan akan berdampak positif bagi kinerja perusahaan. Sementara itu, untuk terlibat karyawan harus mendapatkan stimulus dari atasannya baik dalam bentuk delegasi maupun keteladanan. Hubungan antara atasan dan bawahan tersebut yang akan membuat karyawan bersedia terlibat lebih, sehingga pada akhirnya akan meningkatkan kinerja karyawan.

Penelitian ini didukung oleh Rotenberry (2011), yang secara khusus, menjelaskan adanya dampak signifikan dari work engagement terhadap job performance. Di sisi lain Cohen (2006) menemukan bahwa keterlibatan kerja berpengaruh positif pada kinerja dan Breevaart (2015) melalui hasil penelitiannya menjelaskan bahwa leader member exchange dan work engagement berpengaruh signifikanpada job performance. 


\section{Pengaruh mediasi work engagement yang memediasi leader member exchange terhadap job performance}

Hasil penelitian menunjukkan bahwa kontribusi work engangement agar pengaruhmediasi signifikan tergantung pada korelasi LMX dengan job performance. Semakin tinggi korelasi LMX dengan job performance, maka semakin kecil kontribusi work engagement diperlukan agar mediasinya efektif. Hasil penelitian ini menunjukkan bahwa pengaruh langsung leader member exchange (LMX) pada job performance ternyata lebih besar dibandingkan pengaruh tidak langsung variabel leader member exchange pada job performancemelalui variabel mediasi work engagement. Karena hasilnya masihsignifikan maka dapat disimpulkan bahwa leader member exchange (LMX) berpengaruh signifikan positif terhadap job performance melalui work engagement sebagai variabel intervening dengan mediasi sebagian (partial mediation).

Leader member exchange yang ting i akan menciptakan hubungan yang informal, keadaan ini menciptakan komunikasi yang tinggi antara atasan dan bawahan, dengan komunikasi yang baik, atasan akan dengan mudah menanamkan loyalitas, respek pada profesi untuk meningkatkan kinerja. Secara tidak langsung, leader member exchange juga dapat mempengaruhi kinerja melalui keterlibatan kerja diakrenakan leader member exchange menciptakan vertical dyad, keterlibatan kerja yang baik mengindikasikan karyawan memiliki kinerja yang baik.

Hasil penelitian didukung oleh penelitian yang dilakukan oleh Schaufeli et al. (2006) yang menyatakan bahwa LMX secara signifikan positif berpengaruh terhadap work engagement dan Breevaart (2015) yang dengan tegas mendapat temuan penelitian bahwa work engagement memediasi LMX dengan job performance.Kedua penelitian tersebut saling memperkuat hasil dari penelitian ini.

\section{SI MPULAN}

\section{Simpulan}

1. Terdapat pengaruh positif yang signifikan transformational leadership pada work engagement.

2. Terdapat pengaruh positif yang signifikan antara transformational leadership dan meaning in work pada work engagement.

3. Sesuai dengan perhitungan analisis jalur, pengaruh langsung transformational leadership pada work engagement ternyata lebih besar dibandingkan pengaruh tidak langsung variabel transformational leadership pada work engagement melalui variabel mediasi meaning in work. Karena hasilnya masih signifikan maka dapat disimpulkan bahwa transformational leadership berpengaruh signifikan positif terhadap work engagement melalui meaning in work sebagai variabel intervening dengan mediasi sebagian (partial mediation).

4. Terdapat pengaruh positif yang signifikan leader member exchange pada job performance.

5. Terdapat pengaruh positif yang signifikan antara leader member exchange dan work engagement pada job performance

6. Kontribusi work engangement agar pengaruh mediasi signifikan tergantung pada korelasi LMX dengan job performance. Semakin tinggi korelasi LMX dengan job performance, maka semakin kecil kontribusi work engagement diperlukan agar mediasinya efektif. Hasil penelitian ini menunjukkan bahwa terdapat pengaruh langsung leader member exchange (LMX) pada job performance ternyata lebih besar dibandingkan pengaruh tidak langsung variabel leader member exchange pada job performance melalui variabel mediasi work engagement. Karena hasilnya masih signifikan maka dapat disimpulkan bahwa leader member exchange (LMX) berpengaruh signifikan positif terhadap job 
performance melalui work engagement sebagai variabel intervening dengan mediasi sebagian (partial mediation).

\section{Keterbatasan}

1. Situasi waktu pengisian kuesioner kurang mendukung, dimana peneliti meminta waktu responden ketika sedang bekerja. Sehingga konsentrasi pengisian kuesioner kemungkinan bisa terpecah dengan pekerjaan yang sedang berjalan.

2. Lebih dari $60 \%$ responden level pendidikannya SMA sederajat, dan jabatannya sebagai operator (level bawah), hal ini mempengaruhi wawasan responden dan hasil jawabannya. Ini terlihat dari sering bertanyanya responden kepada peneliti tentang istilah-istilah sukar dalam kalimat pernyataannya.

\section{Saran}

1. Transformational Leadership mempunyai pengaruh positif terhadap Work Engagement. Ini penting diperhatikan perusahaan dalam memilih dan menempatkan karyawan di setiap level jabatannya. Perusahaan sebaiknya memilih pemimpin yang mempunyai gaya kepemimpinan transformasional di setiap level manajemen perusahaan dengan kriteria menjadi pengaruh ideal (idealized influence), inspirasi (inspirational motivation), pengembangan intelektual (intellectual stimulation), dan perhatian pribadi (individualized consideration), sehingga keterlibatan bawahan akan lebih optimal.

2. Meaning in Work berpengaruh positif terhadap Work Engagement. Artinya pemahaman makna kerja setiap karyawan akan mempengaruhi keterlibatan peran dalam bekerja. Dengan melihat kondisional seperti ini, sebaiknya perusahaan memberikan pemahaman tentang Meaning in Work kepada karyawan baik dengan cara komunikasi interpersonal atasan dengan bawahan maupun melalui training.
3. Work Engagement adalah cabang ilmu manajemen yang menarik untuk diteliti dengan segala macam permasalahannya. Sebaiknya peneliti selanjutnya mampu mengeksplorasi lebih dalam baik melalui variasi lokasi penelitian, penambahan jumlah responden maupun mengaitkan variabel lain untuk mengatahui hubungan dan pengaruhnya.

\section{DAFTAR PUSTAKA}

Bass, B.M., B.J. Avolio, D.I. Jung \& Y. Berson. 2003. Predicting unit performance by assessing transformational and transactional leadership. Journal of Applied Psychology. Vol. 88, No. 2, pp. 207218.

Bass, M. Bernard dan Riggio, E. Ronald. 2008. Transformational Leadership. Second Edition. New Jersey: Lawrence Erlbaum Associates, Inc

Bakker, A.B. 2009. Building engagement in the workplace, in Burke, R.J. and Cooper, C.L. (Eds), The Peak Performing Organization, Routledge, Oxon, pp. 50-72.

Bakker, A.B., Albrecht, S.L. and Leiter, M.P. 2011. Key questions regarding work engagement, European Journal of Work and Organizational Psychology, Vol. 20 No. 1, pp. 4-28.

Bakker, A., Demerouti, Evangelia., Xanthoupoulou, Despoina. 2011. How do Engaged Employees Stay Engaged?. Articulo Original Institute of Psychology, Woudestein.

Cohen, J.R. and Single, L.E. 2006. An Examination of The Perceived Impact of Flexible Work Arrangements on Professional Opportunities in Public Accounting. Journal of Business Ethics, Vol. 32 No. 4, pp. 317-28

Danim, Sudarman. 2005. Motivasi Kepemimpinan dan Efektivitas Kelompok. Penerbit Rineka Cipta. 
Fryer, D., \& Payne, R. 1984. Proactive behavior in unemployment : Findings and implication. Leisure Studies, 3, 273-295.

Fryer, D. \& Payne, R. 1984. Working definitions. Quality of Working Life, 1(5), p. 13- 15.

Griffin, Ricky W. 2004. Manajemen, alih bahasa Gina Gania. Jakarta : Erlangga

Humphreys, J.H. 2002. Transformational leader behavior, proximity and successful services marketing. Journal of Services Marketing, Vol. 16, No. 6, pp. 487-502.

Ivancevich, et al. 2006. Organisasi, edisi ke tujuh, penterjemah Gina Gania. Jakarta: Erlangga

Kahn, W.A. 1990. Psychological condition of personal engagement and disengagement at work. Academy of Management Journal, 33 (4), 692.

Liang, \& Crant. 2010. The Role of Proactive Personality in Job Satisfaction and Organizational Citizenship Behavior: A Relational Perspective. Journal of Applied Psychology 2010, Vol. 95, No. 2, 395-404.

Luthans, Fred. 2006. Perilaku Organisasi, (Alih Bahasa V.A Yuwono, dkk), Edisi Bahasa Indonesia, Yogyakarta: ANDI.

Robbins, Stephen P. 2003. Perilaku Organisasi. Edisi Kesembilan, Jilid 2, Terjemahan PT. Indeks Kelompok Gramedia, Jakarta

Robinson, D., Perryman, S., \& Hayday, S. 2004. The drives of work engagement. Brighton: Institute for Employment Studies.
Rotenberry, P.F., \& Moberg, P.J. 2007. "Assessing The Impact of Job Involvement on Performance". Management Research News, 30, 203-215

Schaufeli, W., \& Bakker, A. 2003. UWES (Uterecht Work Engagement Scale). Preliminary Manual. Occupational Health Psychology Unit. Utrecht University .

Schaufeli, W.B., \& Salanova, M. 2001. Work engagement: An emerging psychological concept and its implications for organizations. In S.W. Gilliland, D.D. Steiner \& D.P. Skarlicki, (Eds.), Research in social issues in management (pp. 135-177). Greenwich, CT: Information Age Publishers.

Stoner, J.A.F. et al. 1996. Manajemen. Jakarta : Prenhalindo

Susetyo, Sri Agus. 2015. Keterkaitan antara kepemimpinan transformasional, makna kerja, karakteristik pengikut dan keterlibatan kerja. Pascasarjana UNS. Jurnal Nasional. Vol. 4. Call of Paper UKSW.

Wang, Hui., Law, S.K., and Wang, D.X. 2001. The lingkage Role of LMX: A Mediating Effect of LMX on the Relationship Leadership and Followers' Performance and OCB. Departement of Management of Organization. The Hongkong University of Science and Technology. Clear Water Bay, Kowloon.

Yukl, G.A. 2005. Leadership in Organizations, Prentice Hall, Englewood Cliffs, NJ. 